\title{
Costs of most frequent nursing activities in highly dependent hospitalized patients ${ }^{1}$
}

\author{
Antônio Fernandes Costa Lima² \\ Valéria Castilho ${ }^{3}$ \\ Fernanda Maria Togeiro Fugulin ${ }^{3}$ \\ Belisa Silva ${ }^{4}$ \\ Natália Siqueira Ramin ${ }^{5}$ \\ Talita de Oliveira Melo ${ }^{4}$
}

\begin{abstract}
This quantitative study aimed to identify the costs of the most frequent nursing activities in highly dependent hospitalized patients at a medical clinic. The non-probabilistic convenience sample corresponded to 607 observations regarding oral feeding activities (OF), blood pressure verification (BP) / heart rate (HR), body temperature checking (BTC), performance of intimate hygiene and management of feeding probe. The costs identified corresponded to $\mathrm{R} \$ 2.40$ ( $\mathrm{SD} \pm 2.64$ ) for OF feeding; $\mathrm{R} \$ 1.26$ ( $\mathrm{SD} \pm 0.48$ ) to verify the $B P / H R$; $R \$ 1.17(S D \pm 0.46)$ for $B T C ; R \$ 15.59(S D \pm 8.62)$ to perform intimate hygiene and $R \$ 5.95$ $(\mathrm{SD} \pm 2.13)$ for management of feeding probe. This study will facilitate cost management, with a view to avoiding waste related to unnecessary resource consumption and establish a correlation between costs and care delivery results.
\end{abstract}

Descriptors: Nursing; Direct Service Costs; Costs and Cost Analysis; Cost Control.

\footnotetext{
${ }^{1}$ Supported by Pró-Reitoria de Pesquisa, Universidade de São Paulo, Brazil.

2 PhD, Professor, Escola de Enfermagem, Universidade de São Paulo, Brazil.

${ }^{3} \mathrm{PhD}$, Associate Professor, Escola de Enfermagem, Universidade de São Paulo, Brazil.

${ }^{4}$ Nursing undergraduate student, Escola de Enfermagem, Universidade de São Paulo, Brazil.

${ }^{5}$ RN, Hospital Santa Isabel - Irmandade da Santa Casa de Misericórdia de São Paulo, Brazil.
}

Corresponding Author:

Antônio Fernandes Costa Lima

Universidade de São Paulo. Escola de Enfermagem

Av. Dr Enéas de Carvalho Aguiar, 419

Cerqueira César

CEP: 05403-000, São Paulo, SP, Brasil

E-mail: tonifer@usp.br 


\title{
Custos das atividades de enfermagem realizadas com maior frequência em pacientes de alta dependência
}

Este estudo quantitativo objetivou identificar os custos das atividades de enfermagem realizadas com maior frequência em pacientes de alta dependência, hospitalizados em uma unidade de clínica médica. A amostra de conveniência, não probabilística, correspondeu a 607 observações referentes às atividades alimentação via oral (VO), verificação da pressão arterial (PA) / frequência cardíaca (FC), verificação da temperatura corporal (TC), realização de higiene íntima e administração de dieta via sonda. Os custos identificados corresponderam a $\mathrm{R} \$ 2,40(\mathrm{dp} \pm 2,64)$ para alimentação VO; $R \$ 1,26(d p \pm 0,48)$ para verificação da PA/FC; $R \$ 1,17(d p \pm 0,46)$ para verificação da TC; $R \$ 15,59$ (dp $\pm 8,62)$ para realização da higiene íntima e $R \$ 5,95$ (dp $\pm 2,13)$ para administração de dieta via sonda. Este estudo auxiliará o gerenciamento de custos, visando evitar desperdícios relativos ao consumo desnecessário de recursos, bem como o estabelecimento de correlação entre os custos e os resultados da assistência prestada.

Descritores: Enfermagem; Custos Diretos de Serviços; Custos e Análise de Custo; Controle de Custos.

\section{Costos de las actividades de enfermería realizadas con mayor frecuencia a los pacientes de alta dependencia hospitalizados}

\begin{abstract}
El propósito de este estudio cuantitativo fue identificar los costos de las actividades de enfermería realizadas con mayor frecuencia en pacientes hospitalizados con una unidad de alta dependencia en una clínica médica. La muestra de conveniencia, no probabilística, correspondió a 607 observaciones en relación a las actividades de alimentación por vía oral (VO); verificación de la presión arterial (PA) / frecuencia cardiaca (FC), verificación de la temperatura corporal (TC); realización de la higiene íntima y la administración de alimentación a través de la sonda. Los costos identificados correspondía a $R \$ 2,40$ $(\mathrm{DP} \pm 2,64)$ para la alimentación de $\mathrm{VO} ; \mathrm{R} \$ 1,26(\mathrm{DP} \pm 0,48)$ para verificar la $\mathrm{PA} / \mathrm{FC}$; $\mathrm{R} \$ 1,17(\mathrm{DP} \pm 0,46)$ para la verificación de la $T C ; \mathrm{R} \$ 15,59(\mathrm{DP} \pm 8,62)$ para la realización de la higiene íntima y $\mathrm{R} \$ 5.95$ ( $\mathrm{DP} \pm 2,13)$ para la administración a través de la sonda de alimentación. Este estudio ayudará a administrar los costos con el fin de evitar que los desechos relacionados con el consumo innecesario de recursos, así como el establecimiento de una correlación entre los costos y resultados de la atención.
\end{abstract}

Descriptores: Enfermería; Costos Directos de Servicios; Costos y Análisis de Costo; Control de Costos.

\section{Introduction}

According to the Brazilian Institute of Geography and Statistics, the hospitalization coefficient (number of hospitalizations divided by the number of inhabitants), the hospitalization rate (number of hospitalization days consumed per inhabitant and year) and the hospitalization cost rate (hospitalization cost consumed per inhabitant) of the Unified Health System are higher for the age range over 60 years than for any other age range in the Brazilian population. It is even observed that the hospitalization rate and the hospitalization cost rate increase progressively after that age and that the occurrence of rehospitalization among the elderly is five times higher than in the age range between 15 and 59 years $^{(1)}$.

It is estimated that $85 \%$ of the elderly suffer from at least one chronic disease, at least $10 \%$ of whom have 
five concomitant problems ${ }^{(2)}$. In hospital contexts, it is observed that this association is directly related with the elderly's dependence level on nursing care.

It is highlighted that nurses who administer health units are responsible for human, material and physical resource management, demanding great financial resources. According to the institution's characteristics, nursing represents between 30 and $60 \%$ of the total staff. The volume of materials nurses manage at the different units is another important factor with regard to a health organization's costs. Thus, nurses have been pressured at their workplaces to reduce staff and material without, however, knowing the expense profile, relating it with care production and analyzing its costs ${ }^{(3)}$.

This evidences the need for research on the costs of care delivery to hospitalized patients who are highly dependent on nursing and which permits knowledge on the costs of activities in these patients' care plan.

\section{Aim}

To identify the mean total direct cost (MTDC) of the most frequent activities for patients who are highly dependent on nursing care and hospitalized at the medical clinic.

\section{Method}

\section{Study design}

An exploratory and descriptive case study with quantitative data analysis was developed.

\section{Place of study}

The study was developed at the Medical Clinic (MC) of the University Hospital (UH) at the University of São Paulo (USP), as its human and structural resources contribute to the best practices in nursing care. The Unit offers 41 beds for care delivery to patients coming from the Adult Emergency Unit, Outpatient Clinic, Adult Intensive Care Unit and other hospital units.

The MC nurses offer the places for patient hospitalization and classify them according to the care type $^{(4)}$. During the research period, 14 beds were reserved for highly dependent and 29 for intermediate care patients. Each day, all hospitalized patients are assessed and classified and, when necessary, reorganized to the bed corresponding to their care profile.

In recent years, empirical evidence exists about the growth of the hospitalized elderly population at the MC. This population comprises chronic patients who are stable from a clinical viewpoint, but completely dependent on nursing actions to have their basic human needs attended to. According to these characteristics, the unit nurses classify them as Highly Dependent on Nursing (HDN) in Fugulin's Patient Classification System(4).

The profile of HDN patients mostly corresponds to elderly and/or chronic patients. They share the characteristic of total dependence for feeding, bathing, hygiene, mobilization and/or need constant surveillance, due to states of mental confusion or other neurocognitive alterations ${ }^{(5)}$.

At the MC, the nurses manage the patients' care plan by means of the Nursing Process (NP), with a view to appropriate decision making on their care needs (diagnoses), what outcomes are intended (outcomes/ targets) and what is the best care to see to those needs in view of the desired outcomes (interventions/ activities)(6). To put in practice an intervention that helps the patient to achieve the desired outcome, they prescribe nursing activities, defined in the Nursing Interventions Classification(7) as specific actions or behaviors performed by nurses and, in the Brazilian reality, by nursing technicians and auxiliary nurses as well. The Unit has a nursing procedure manual to support the execution of the interventions, describing each recommended activity and distinguishing the standard materials needed for its accomplishment.

\section{Ethical aspects}

Data were collected after the research project received approval from the Research Ethics Committee and the institution's Research Ethics Committee (Registration Protocol N. 990/05 - SISNEP CAAE: 0018.0.198.196-10).

\section{Cases/Sample}

The cases corresponded to the opportunities to observe the activities nursing team professionals (nurses, nursing technicians and auxiliary nurses) accomplish most frequently for care delivery to HDN patients hospitalized at the MC, during morning and afternoon shifts, in July 2010 and January and February 2011, totaling 24 days. The months chosen and the number of days are justified by the fact that three nursing undergraduates with specific training performed the observations during holiday periods.

Initially, the identification of the accomplished activities was based on a recent study(5) at the Unit, in 
which HDN patients obtained the following basic activities as Nursing Activities Score ${ }^{(8)}$ items: medication, except vasoactive drugs (100\%); mobilization and positioning: accomplishment of the procedure more than thrice or involving two persons (95.95\%); accomplishment of hygiene procedures taking less than two hours (90.07\%); monitoring and controls: observation and/or continuous activity during two hours or more $(84.58 \%)$; quantitative urinary output measure (71.11\%) and treatment to improve the pulmonary function (51.50\%). Then, these activities were complemented and detailed by consulting the nurses active at the MC.

Twenty-nine items were identified and, in those study, those activities will be presented that were performed most frequently during the study period. Hence, a non-probabilistic convenience sample was used, totaling 607 observations of five nursing activities: oral feeding activities (OF) $(n=176)$, blood pressure $(B P)$ / heart rate $(H R)$ verification $(n=114)$, body temperature checking (BTC) $(n=114)$, performance of intimate hygiene $(n=108)$ and management of feeding probe $(n=95)$.

\section{Data collection}

To calculate the nursing activity costs, worksheets were elaborated to register the consumption of materials, the category and number of nursing professionals involved and the time spent to perform each activity.

Costs were verified using direct costing, defined as a monetary expense applied in the production of a product or service and which can be identified to the product or department. Direct cost is any cost that can be measured, i.e. identified and clearly quantified ${ }^{(9)}$. At hospital units, these basically involve labor, material and equipment used directly in the care process ${ }^{(10)}$.

Direct labor ( $D L)$ refers to the staff that works directly on a product or service delivery, provided that the time spent can be measured and the person who performed the work can be identified. It includes salaries, social charges, accrued vacation pay and thirteenth salary ${ }^{(9)}$.

\section{DL costs}

The calculation of the DL unit cost was based on the mean salaries per professional category, as informed by the Financial Manager of the University Hospital-USP, based on the nursing staff working at the MC during the data collection period: nurse $R \$ 8,118.78$; technician $\mathrm{R} \$ 4,306.14$ and auxiliary nurse $\mathrm{R} \$ 5,553.53$. At USP, no difference exists between the initial salaries for the nursing technician and auxiliary nurse categories. Therefore, since 2003, the Nursing Department (ND) at the hospital has only selected technicians, as these professionals have a more in-depth educational background than the auxiliary nurses. The auxiliary nurses working at the MC have been active at the institution longer and, therefore, their mean salary is higher, due to the benefits gained over the years.

As nursing professionals have a 36-hour weekly work journey at the hospital, DL costs corresponded to: nurse $\mathrm{R} \$ 56.38$ per hour and $\mathrm{R} \$ 0.93$ per minute; technician $\mathrm{R} \$ 29.90$ per hour and $\mathrm{R} \$ 0.49$ per minute and nursing auxiliary $\mathrm{R} \$ 38.56$ per hour and $\mathrm{R} \$ 0.64$ per minute.

\section{Material and clothing costs}

The Material, Warehouse and Equity Section of the hospital informed the material costs, complemented when necessary by the nurse responsible for material management at the ND. In this study, permanent equipment (digital blood pressure and cardiac frequency meters, stethoscope, digital thermometer and folding screen) costs at the MC were not surveyed, nor the cost of the enteral diet administration pump, as this equipment is on consignment.

Information on clothing costs was obtained from the Director of the hospital's Specialized Hygiene Service (SHS). Cost calculations were based on SHS professionals' estimate that each piece of clothing can be used 100 times at most. Processing costs per piece of clothing were added according to weight, considering that the institution pays $\mathrm{R} \$ 1.77$ per kilogram of clothing.

\section{MTDC calculation}

The MTDC of the most frequent nursing activities for HDN patients was calculated by multiplying the time the nursing professionals spent by the unit cost of $\mathrm{DL}$ and adding material costs. All calculations were elaborated in the Brazilian currency $(R \$)$.

\section{Data analysis and treatment}

The collected data were entered into electronic worksheets and submitted to pertinent statistical tests. The variables were subject to descriptive analysis through the observation of minimum and maximum values, calculation of means, standard deviations, medians and mode and displayed in tables. SPSS 15.0 for Windows e Excel were used for the calculations. 


\section{Results}

The five most frequent activities were identified, related to interventions that involve direct care, i.e. treatments performed through interaction with the patient, which represent physiological nursing actions and comprise practical actions(6).
These nursing activities involving patients the nurses had classified as HDN totaled 607 observations and will be presented according to observation opportunity frequencies. The duration of each activity will be shown descriptively, some in minutes and others in seconds, as well as their MTDC, including staff, standard material as established in the ND nursing procedure manual and/or extra material consumption.

Table 1 - Mean, standard deviation (SD), median, minimum, maximum and mode for the duration and cost of oral feeding (OF) activities. São Paulo, SP, Brazil, 2011

\begin{tabular}{lcccccc}
\hline \multicolumn{1}{r}{ Variable } & N & Mean & SD & Median & Minimum & Maximum \\
\hline Duration (in minutes) & 176 & 4.34 & 4.09 & 3.00 & 1.00 & 21.00 \\
Staff cost & 176 & 2.40 & 2.64 & 1.47 & 0.49 & 18.60 \\
Total cost (in R\$) & 176 & 2.40 & 2.64 & 1.47 & 0.49 & 18.60 \\
\hline
\end{tabular}

In Table 1, it is observed that the duration of the OF activity ranged between 1.00 and 21.00 minutes, with a mean 4.34 minutes (SD \pm 4.09 ) and mode equal to 1.00 .

Only staff cost was involved in this activity, varying between $R \$ 0.49$ and $R \$ 18.60$, with a MTDC of $R \$ 2.40$ $(\mathrm{SD} \pm 2.64)$ and $\mathrm{R} \$ 0.49$ as the most frequent amount.

The total accumulated staff cost for the 176 activities observed was $\mathrm{R} \$ 86.24$.

Table 2 - Mean, standard deviation (SD), median, minimum, maximum and mode for the duration and cost of BP/HR verification activities. São Paulo, SP, Brazil, 2011

\begin{tabular}{lcccccc}
\hline \multicolumn{1}{c}{ Variable } & N & Mean & SD & Median & Minimum & Maximum \\
\hline Duration (in seconds) & 114 & 147.85 & 52.61 & 150.00 & 60.00 & 320.00 \\
Staff cost (in R\$) & 114 & 1.26 & 0.48 & 1.23 & 0.49 & 2.94 \\
Total cost (in R\$) & 114 & 1.26 & 0.48 & 1.23 & 0.49 & 2.94 \\
\hline
\end{tabular}

The analysis of Table 2 shows that the duration of $\mathrm{BP} / \mathrm{HR}$ verification activities ranged between 60.00 and 320.00 seconds, with a mean 147.85 seconds (SD \pm 52.61$)$ and mode equaling 150.00. Only staff costs were involved in this activity, varying between $\mathrm{R} \$ 0.49$ and $\mathrm{R} \$ 2.94$, with an MTDC of $\mathrm{R} \$ 1.26(\mathrm{SD} \pm 0.48)$ and $\mathrm{R} \$$ 1.23 as the most frequent value.

The total accumulated staff cost for the 114 activities observed was $\mathrm{R} \$ 143.64$.

Table 3 - Mean, standard deviation (SD), median, minimum, maximum and mode for the duration and cost of BTC activities. São Paulo, SP, Brazil, 2011

\begin{tabular}{lcccccc}
\hline \multicolumn{1}{c}{ Variable } & N & Mean & SD & Median & Minimum & Maximum \\
\hline Duration (in seconds) & 114 & 130.48 & 55.03 & 120.00 & 40.00 & 420.00 \\
Staff cost (in R\$) & 114 & 1.10 & 0.46 & 0.98 & 0.33 & 3.43 \\
Total cost (in R\$) & 114 & 1.17 & 0.46 & 1.05 & 0.40 & 3.50 \\
\hline
\end{tabular}

In Table 3, it is observed that the duration of BTC activities ranged between 40.00 and 420.00 seconds, with a mean 130.48 seconds $(S D \pm 55.03)$ and mode equaling 120.00. Staff costs varied between $R \$ 0.33$ and $\mathrm{R} \$ 3.43$, with a mean $\mathrm{R} \$ 1.10(\mathrm{SD} \pm 0.44)$ and mode equal to $\mathrm{R} \$ 0.98$.
The MTDC related to the activity, involving staff and standard material costs ( $\$ \$ 0.07)$, corresponded to $\mathrm{R} \$ 1.17$ and the most frequent amount was $\mathrm{R} \$ 1.05$.

The total accumulated staff cost for the 114 activities observed was $\mathrm{R} \$ 133.38$. 
Table 4 - Mean, standard deviation (SD), median, minimum, maximum and mode for the duration and cost of intimate hygiene performance. São Paulo, SP, Brazil, 2011

\begin{tabular}{|c|c|c|c|c|c|c|c|}
\hline Variable & $\mathbf{N}$ & Mean & SD & Median & Minimum & Maximum & Mode \\
\hline Duration (in minutes) & 108 & 7.81 & 4.45 & 7.00 & 2.00 & 24.00 & 5.00 \\
\hline Staff cost & 108 & 7.30 & 5.13 & 5.88 & 0.98 & 27.12 & 4.90 \\
\hline Standard material cost & 108 & 5.57 & 4.52 & 4.72 & 0.28 & 25.53 & 2.87 \\
\hline Extra material cost & 108 & 2.72 & 1.96 & 2.22 & 0.00 & 6.87 & 0.85 \\
\hline Total cost (in $\mathrm{R} \$$ ) & 108 & 15.59 & 8.62 & 14.08 & 1.75 & 41.44 & 8.27 \\
\hline
\end{tabular}

Table 4 shows that the duration of intimate hygiene activities ranged between 2.00 and 24.00 minutes, with a mean 7.81 minutes ( $S \pm 4.45)$ and mode equal to 5.00. Staff costs in this activity varied between $\mathrm{R} \$ 0.98$ and $\mathrm{R} \$ 27.12$, with a mean $\mathrm{R} \$ 7.30(\mathrm{SD} \pm 5.13)$ and mode of $\mathrm{R} \$ 4.90$. Standard material costs ranged between $\mathrm{R} \$ 0.28$ and $\mathrm{R} \$ 25.53$, with a mean $\mathrm{R} \$ 5.57$ ( $\mathrm{SD} \pm 4.52$ ) and mode equal to $R \$ 2.87$.

The following extra material was used: gown, long-sleeved protection apron, adult disposable diaper, mobile sheet, representing an additional $\mathrm{R} \$ 2.72$ in total activity costs.

The MTDC of the activity equaled R $\$ 15.59$, with $\mathrm{R} \$ 12.87$ of staff and standard material costs and $\mathrm{R} \$ 2.72$ of extra material costs. The most frequent amount was $\mathrm{R} \$ 8.27$.

The total accumulated cost for the 108 activities observed was $\mathrm{R} \$ 1,683.72$, with $\mathrm{R} \$ 788.40$ (46.82\%) spent on staff, $\mathrm{R} \$ 601.56$ (35.72\%) on standard material and $R \$ 293.76$ (17.23\%) on extra material.

Table 5 - Mean, standard deviation (SD), median, minimum, maximum and mode for the duration and cost of management of feeding probe activities. São Paulo, SP, Brazil, 2011

\begin{tabular}{|c|c|c|c|c|c|c|c|}
\hline Variable & $\mathbf{N}$ & Mean & SD & Median & Minimum & Maximum & Mode \\
\hline Duration (in minutes) & 95 & 3.13 & 1.52 & 3.00 & 1.00 & 6.00 & 2.00 \\
\hline Staff cost & 95 & 1.59 & 0.82 & 1.47 & 0.49 & 4.65 & 0.98 \\
\hline Standard material cost & 95 & 4.18 & 1.90 & 5.03 & 0.00 & 5.70 & 5.03 \\
\hline Extra material cost & 95 & 0.18 & 0.26 & 0.00 & 0.00 & 0.56 & 0.00 \\
\hline Total cost (in $\mathrm{R} \$$ ) & 95 & 5.95 & 2.13 & 6.50 & 0.49 & 8.87 & 6.99 \\
\hline
\end{tabular}

The analysis of Table 5 shows that the duration of feeding probe management activities ranged between 1.00 and 6.00 minutes, with a mean 3.13 minutes $(S D \pm 1.52)$ and mode equal to 2.00. Staff costs for this activity varied between $\mathrm{R} \$ 0.49$ and $\mathrm{R} \$ 4.65$, with a mean $\mathrm{R} \$ 1.59(\mathrm{SD} \pm 0.82)$ and mode equaling $\mathrm{R} \$ 0.98$. Standard material costs varied between $\mathrm{R} \$ 0.00$ and $\mathrm{R} \$ 5.70$, with a mean $\mathrm{R} \$ 4.18(\mathrm{SD} \pm 1.90)$ and mode equal to $R \$ 5.03$.

The following extra material was used: medium procedure glove, representing an average additional cost of $\mathrm{R} \$ 0.18$ in total activity costs.

The MTDC for this activity totaled $\mathrm{R} \$ 5.95$, with $\mathrm{R} \$ 5.77$ related to staff and standard material costs and $\mathrm{R} \$ 0.18$ to extra material. The most frequent amount was $\mathrm{R} \$ 6.99$.

The total accumulated cost for the 95 activities observed was $R \$ 565.25$, with $R \$ 151.05$ (26.7\%) spent on staff, $\mathrm{R} \$ 397.10$ (70.3\%) on standard material and $\mathrm{R} \$ 17.10$ (3.0\%) on extra material.

\section{Discussion}

During the study period, occupation rates at the MC corresponded to $87.9 \%$ in July $2010,97.2 \%$ in January and $96.4 \%$ in February 2011, showing typical months at the unit, whose mean occupation rate exceeds $85.5 \%$

The most frequent activities observed involve some characteristics of patients classified in the HDN care category: stable vital signs (87.84\%); bedridden (66.80\%); oral feeding with nursing support (59.74\%); eliminations in bed and/or use of urinary catheter for diuresis control $(57.12 \%)^{(5)}$.

At the MC unit, due to the HDN patients' profile, the nurses prescribe the verification of vital signs, although stable, at least thrice per day. For some of these patients, BP, HR, RF verification and BTC activities can be prescribed separately, at shorter intervals, with a view to attending to specific control needs.

In this study, activities related to indirect care interventions, performed distanced from the patients 
but in their benefit, which involve unit management and interdisciplinary cooperation actions ${ }^{(7)}$, were not included in the cost verification. Therefore, it is highlighted that all direct and indirect care activities need to be identified in order to fully cover the costs of nursing care delivery to HDN patients.

The obtained results, however, can help the MC unit nurses to review the nursing procedure manual and adapt material consumption with a view to avoiding waste, in partnership with the nurses from the Educational Support Service.

Studies ${ }^{(12-14)}$ evidence that, among different types of waste by nursing professionals and physicians, materialrelated waste is the most mentioned. It is highlighted that material resource management has aroused public and private health institution managers increasing concern, due to the high cost this has represented for these institutions ${ }^{(15)}$.

Nurses correspond to an important decision level in resource allocation when they decide on service priorities at their work units and on what resources will be used to accomplish these. This is already the case at some private and public hospitals, where the nurse, as the manager of her business unit, assesses needs related to material, physical, human and financial resources; critical assesses unit expenses on a monthly base, comparing actual and budgeted expenses; and participates in budget planning for the upcoming year ${ }^{(16)}$.

The global reality shows that health services are being confronted with a growing range of health needs and financial constraints, which limit investments in the sector's infrastructure and workforce ${ }^{(17)}$ and can result in insufficient nursing staff to maintain the patient care security and quality ${ }^{(18)}$.

The quality of the services a health institution delivers highly depends on its workers' technical competency and user interaction and communication skills, but also depends on other aspects, including ongoing work conditions and available material resources and support services ${ }^{(19)}$.

It is obvious that, among the actions the nursing team performs, technical procedures entail risks and demand continuous assessment by the Nursing Services, with a view to guaranteeing the quality of the care process ${ }^{(20)}$. Professionals also need to keep in mind, however, that care delivery has its costs, and knowing these costs can trigger reflections and discussions on the judicious and adequate use of the available, but not unlimited human and material resources.

In view of this panorama, cost management by nurses becomes fundamental with a view to decision making on efficient rationalization in the allocation of available and limited resources, with a view to achieving results that are coherent with clients' health needs and institutional needs/goals. Therefore, they need to understand a set of principles and know about economic analyses that permit choosing the most convenient decisions $^{(21)}$.

\section{Conclusions}

At the MC unit of the University Hospital affiliated with the University of São Paulo, 607 observations were made on 24 data collection days, during morning and afternoon shifts, related to OF, BP/HR verification, BTC, intimate hygiene and feeding probe management activities, which were identified as the most frequent during the study period.

The identified MTDC equaled $R \$ 2.40(S D \pm 2.64)$ for $\mathrm{OF}$; $\mathrm{R} \$ 1.26(\mathrm{SD} \pm 0.48)$ for $\mathrm{BP} / \mathrm{HR}$ verification; $R \$ 1.17$ ( $S D \pm 0.46$ ) for $B T C$; $R=15.59$ ( $S D \pm 8.62$ ) for intimate hygiene and $R \$ 5.95(S D \pm 2.13)$ for feeding probe management.

The lack of similar studies that permit discussing the obtained results is considered a study limitation. Nevertheless, it will help the MC nurses with cost management, so as to avoid waste related to the unnecessary consumption of human and/or material resources, as well as to correlate cost measurement with the analysis of care delivery results. Identifying the MTDC of all nursing activities will enhance knowledge on the cost of direct and indirect care delivery to HDN patients and, in that perspective, this research will be continued.

\section{References}

1. Instituto Brasileiro de Geografia e Estatística. A condição dos idosos no domicílio. In: perfil dos idosos responsáveis pelos domicílios no Brasil. Rio de Janeiro; 2002. 58 p.

2. Ramos LR. Epidemiologia do envelhecimento. In: Freitas EV et al. Tratado de geriatria e gerontologia. Rio de Janeiro: Ed. Guanabara Koogan, 2000. 72-8p.

3. Castilho V, Fugulin FMT, Gaidzinski RR. Gerenciamento de custos nos serviços de enfermagem. In: Kurcgant $P$, coordenador. Gerenciamento em Enfermagem. $2^{\text {a }}$ ed. Rio de Janeiro (RJ): Guanabara Koogan; 2010. p. 169-80.

4. Fugulin FMT, Gaidzinski RR, Kurcgant P.Patient classification system: identification of the patient care profile at hospitalization units of the UH-USP. Rev. Latino-Am. Enfermagem. [periódico na Internet]. 2005 
Fev [acesso 19 nov 2011] ; 13(1):72-8. Disponível em: $\quad$ http://www.scielo.br/scielo.php?script=sci_ arttext\&pid $=$ S0104-11692005000100012\&lng $=$ pt. h t t p : / / dx.doi.org/10.1590/S010411692005000100012.

5. Tsukamoto R. Tempo médio de cuidado ao paciente de alta dependência de enfermagem segundo o Nursing Activities Score (NAS) [dissertação]. São Paulo (SP): Escola de Enfermagem da Universidade de São Paulo; 2010.

6. Cruz DALM. Processo de enfermagem e classificações. In: Gaidzinski RR, Soares AVN, Lima AFC, Gutierrez BAO, Cruz DALM, Rogenski NMB, et al. Diagnósticos de enfermagem na prática clínica. Porto Alegre: Artmed; 2008. p. 21-633.

7. Bulechek GM, Butcher HK, Dochterman JM. Nursing Interventions Classification (NIC). 5rd ed. St Louis: Mosby; 2008.

8. Queijo AF. Tradução para o português e validação de um instrumento de medida de carga de trabalho de enfermagem em Unidade de Terapia Intensiva: Nursing Activities Score (N.A.S.). [dissertação]. São Paulo (SP): Escola de Enfermagem da Universidade de São Paulo; 2002.

9. Martins, E. Contabilidade de custos. 9a ed. São Paulo: Atlas; 2003.

10. Castilho V. Gerenciamento de custos: análise de pesquisas produzidas por enfermeiras. [tese livredocência]. São Paulo (SP): Escola de Enfermagem da Universidade de São Paulo; 2008

11. Lima AFC, Gutierrez BAO. O Sistema de Assistência de Enfermagem na Divisão de Enfermagem Clínica. In: Gaidzinski RR, Soares AVN, Lima AFC, Gutierrez BAO, Cruz DALM, Rogenski NMB, et al. Diagnósticos de enfermagem na prática clínica. Porto Alegre: Artmed; 2008. p. 85-126.

12. Castilho V, Castro LC, Couto AT, Maia FOM, Sasaki NY, Nomura FH, et al . Survey major source of wasted health care units of a university hospital. Rev Esc Enferm USP. [periódico na Internet ]. 2011 Dez [acesso 9 mai 2012] ; 45(spe):1613-20. Disponível em: http://www. scielo.br/scielo.php?script=sci_arttext\&pid=S0080$62342011000700012 \&$ Ing $=p t$. http://dx.doi. org/10.1590/S0080-62342011000700012.

13. Aranha GTC, Vieira RW. Estudo de um dos indicadores do custo da qualidade: o desperdício. Rev Adm Saúde. $2004 ; 23(6): 43-55$.
14. Sacramento FJS. Identificação de fontes de desperdício em instituições hospitalares [dissertação]. São Bernardo do Campo: Universidade Metodista de São Paulo; 2001.

15. Castilho V, Gonçalves VLM. Gerenciamento de recursos materiais. In: Kurcgant $\mathrm{P}$, coordenadora. Gerenciamento em enfermagem. $2^{\mathrm{a}}$ ed. Rio de Janeiro: Guanabara Koogan; 2010. p. 155-67.

16. Zunta RSB, Castilho V. Billing of nursing procedures at an intensive care unit. Rev. Latino-Am. Enfermagem [periódico na Internet]. 2011 Jun [acesso 19 nov 2011] ; 19(3):573-80. Disponível em: http://www. scielo.br/scielo.php?script=sci_arttext\&pid=S0104 $11692011000300017 \&$ Ing $=$ pt. http://dx.doi. org/10.1590/S0104-11692011000300017.

17. Baumann A. Positive practice environments: quality workplaces = quality patient care. Geneva: International Council of Nurses; 2007.

18. Lima KF, Tsukamoto R, Fugulin FTM. Aplicação do Nursing Activities Score (NAS) em pacientes de Alta Dependência de enfermagem. Texto \& Contexto Enferm. 2008;17(4):638-46.

19. Nonino EAPM, Anselmi ML, Dalmas JC. Quality assessment of the wound dressing procedure in patients at a university hospital. Rev. Latino-Am. Enfermagem. [periódico na Internet]. 2008 Feb [acesso 21 nov 2011] ; 16(1):57-63. Disponível em: http://www. scielo.br/scielo.php?script=sci arttext\&pid=S010411692008000100010\&lng=en. http://dx.doi. org/10.1590/S0104-11692008000100010.

20. Peduzzi M, Anselmi ML. Os pressupostos, o desenho e os resultados da pesquisa de avaliação do impacto do PROFAE na qualidade dos serviços de saúde. In: Castro JL, organizadora. Profae: Educação profissional em saúde e cidadania. Brasília (DF): Ministério da Saúde (BR); 2002. p. 151-64.

21. Francisco IMF, Castilho V. The nursing and the management costs. Rev Esc Enferm USP. [periódico na Internet]. 2002 Sep [acesso 10 nov 2011] ; 36(3):240-4. Disponível em: http://www.scielo. br/scielo.php?script =sci_arttext\&pid=s008062342002000300005\&lng=pt. http://dx.doi. org/10.1590/S0080-62342002000300005. 